\begin{tabular}{l} 
2. To: (Receiving Organization) \\
Distribution \\
\hline 5. Proj./Prog./Dept./Div.: \\
Fiscal Year 1999 Memorandum \\
of Understanding/Waste \\
Management/TB\&P/Process \\
Engineering
\end{tabular}

8. Originator Remarks:

This document is being released into the supporting document system for retrievability purposes.
3. From: (Originating Organization) Technical Basis and Planning
6. Design Authority/ Design Agent/Cog. .Engr.: Ruth D. Schreiber

4. Related EDT No.:

$\mathrm{N} / \mathrm{A}$

7. Purchase Order No.:

$\mathrm{N} / \mathrm{A}$

11. Receiver Remarks: MA. Design Baseline Document? [] Yes [X] No For release.

9. Equip./Component No.: $\mathrm{N} / \mathrm{A}$

10. System/Bldg./Facility: $\mathrm{N} / \mathrm{A}$

12. Major Assm. Dwg. No.: $N / A$

13. Permit/Permit Application No.: $\mathrm{N} / \mathrm{A}$

14. Required Response Date: $11 / 04 / 98$

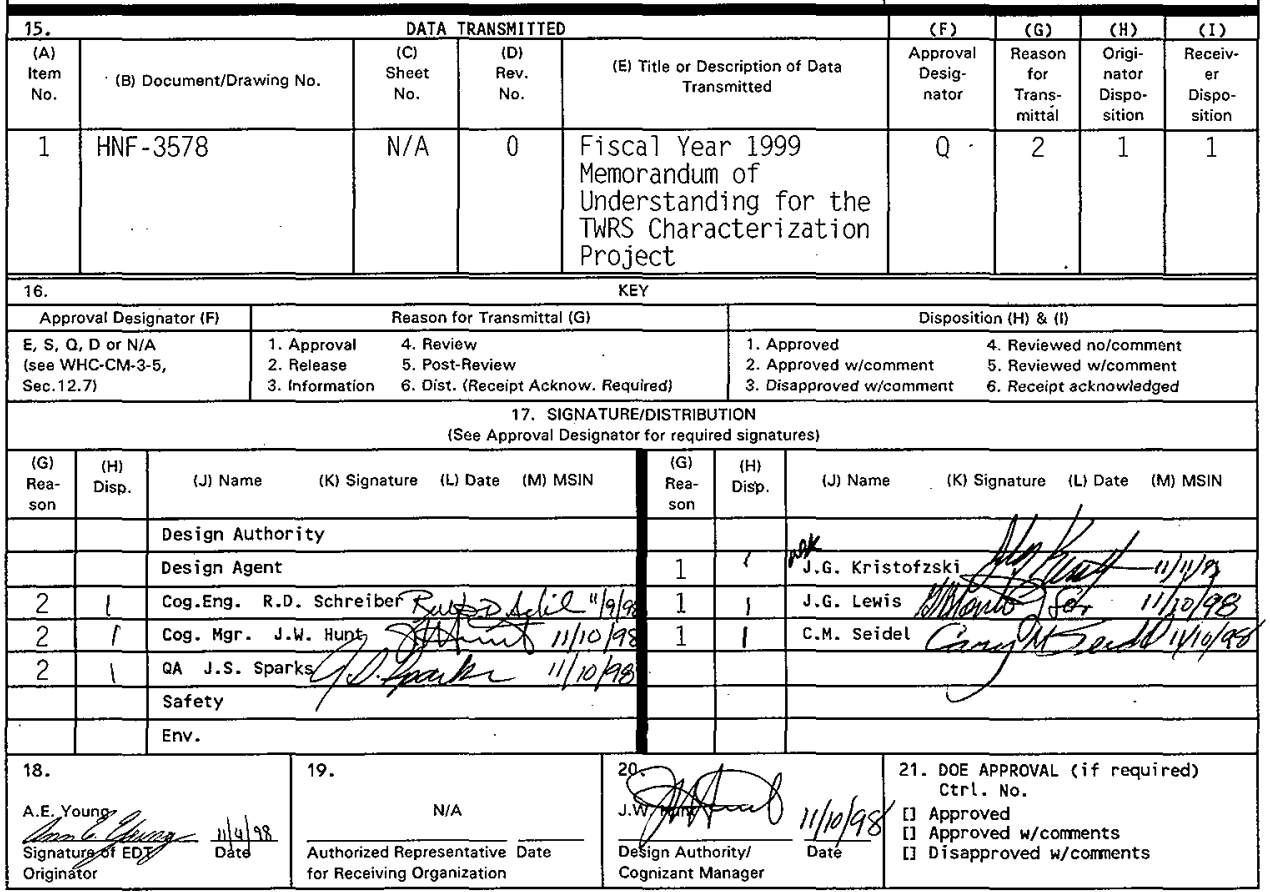

BD-7400-172-2 (05/96) GEF097 


\section{Fiscal Year 1999 Memorandum of Understanding for the TWRS Characterization Project}

Ruth D. Schreiber

Lockheed Martin Hanford. Corp., Richland, WA 99352

U.S. Department of Energy Contract DE-AC06-96RL13200

$\begin{array}{lll}\text { EDT/ECN: } & \text { EDT-622492 } & \text { UC: } 2070 \\ \text { Org Code: } & 74 \text { B10 } & \text { Charge Code: CACN 102213/COA EI00 } \\ \text { B\&R Code: } & \text { EW } 3120074 & \text { Total Pages: } 20\end{array}$

Key Words: Fiscal Year 1999, Memorandum of Understanding, MOU, TWRS, Characterization. Project

Abstract: N/A

TRADEMARK DISCLAIMER. Reference herein to any specific comercial product, process, or service by trade name, trademark, manufacturer, or otherwise, does not necessarily constitute or imply its endorsement, recommendation, or favoring by the United States Government or any agency thereof or its contractors or subcontractors.

Printed in the United States of Anerica. To obtain copies of this document, contact: Document Control Services, 9.0. Box 950, Mailstop H6-08, Richland WA 99352, Phone (509) 372-2420; Fax (509) 376-4989.
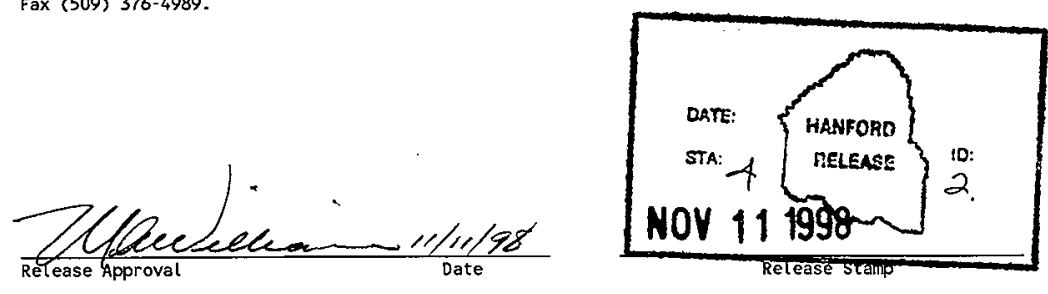

\section{Approved for Public Release}




\section{Fiscal Year 1999 Memorandum of Understanding for the TWRS Characterization Project}

R. D. Schreiber

Lockheed Martin Hanford Corporation

Date Published

November 1999

Prepared for the U.S. Department of Energy

Office of Environmental Restoration and Waste Management 
HNF-3578, REV. 0

\subsection{INTRODUCTION}

During fiscal year 1999, the level of success achieved by the Tank Waste Remediation System (TWRS) shall be determined by specific performance measures. These measures take the form of significant deliverables, one of which is the completion of Tank Characterization Reports (TCRs). In order to achieve success regarding the TCR performance deliverable, multiple organizations across TWRS must work together. Therefore, the requirements and expectations needed from each of these TWRS organizations were examined in order to gain an understanding of the performance necessary from each organization to achieve the end deliverable. This memorandum of understanding (MOU) documents the results of this review and establishes the performance criteria by which TWRS will assess its progress and success. These criteria have been determined based upon a TWRS Characterization Project budget of $\$ 42.1$ million for fiscal year 1999; if this budget is changed or the currently identified workscope is modified, this MOU will need to be revised accordingly.

This MOU is subdivided into six sections, where sections three through six each identify individual interfaces between TWRS organizations. The specific performance criteria related to each TWRS organizational interface are then delineated in the section, along with any additional goals or issues pertaining to that interface.

\subsection{SUMMARY OF INTERFACE PROGRAM RESPONSIBILITIES}

This section provides a brief summary of each interface program and its generic responsibilities.

\subsection{TWRS Process Engineering}

TWRS Process Engineering, through the Tank Coordinator (TC) role, is responsible for providing direction to the 222-S Laboratory and Characterization Project Operations (CPO). Direction is primarily provided via the Tank Sampling and Analysis Plan (TSAP), although other work-authorizing documents such as letters of instruction (LOIs) are also used in special circumstances. The TSAP is the primary documentation for initiating field work and analytical services. Additionally, CPO uses a work package as a driver for sampling activity. One TSAP is required for each sampling event in a tank (e.g., core, auger, grab, or vapor sampling), except in those cases where a generic TSAP has been generated. The contents of a TSAP are delineated in the Tank Waste Remediation System Process Engineering Instruction Manual (Adams 1998). 
HNF-3578, REV. 0

\subsection{2-S Laboratory}

The 222-S Laboratory is responsible for providing tank waste analysis results in accordance with the requirements provided in the TSAP. The results of these analyses and quality control protocols are to be in conformance with the 222-S Laboratory Quality Assurance Plan (Markel 1998), the Tank Waste Remediation System, Characterization Project, Quality Policies (Board 1998), and Hanford Analytical Services Quality Assurance Requirements Document (DOE 1997), as well as required internal quality control reviews. The standard data reporting formats required for use by the 222-S Laboratory are discussed in Appendix A of this MOU.

\subsection{Characterization Project Operations}

CPO performs intrusive work in the underground storage tanks, including the sampling of the tanks to satisfy requirements identified in the TSAP. The TSAP initiates field work and is necessary to transmit requirements not found in the work package, although work packages are the primary documentation necessary to obtain samples from tank farms. All intrusive activities are performed in accordance with approved work packages, which must conform to the governing TSAP.

\subsection{TWRS Quality Assurance}

TWRS Quality Assurance (TWRS QA) supports and oversees the quality assurance goals covering all Characterization Project activities. With respect specifically to the TCR process, TWRS QA reviews and approves all TSAPs and ensures compliance with quality assurance requirements while obtaining samples.

\subsection{PRE-SAMPLING PLANNING INTERFACE}

This section summarizes the performance measures pertaining to the pre-sampling planning activities performed by TWRS Process Engineering, 222-S Laboratory, CPO, and TWRS QA.

\subsection{TWRS Process Engineering Performance Criteria}

The overall goal of the TWRS Process Engineering organization is to have at least two TSAPs completed and issued for each sampling type or truck at all times to facilitate flexibility in the field. To reach this goal, TWRS Process Engineering should provide the TSAP to the 222-S Laboratory and $\mathrm{CPO}$ at least 8 working days prior to the beginning of the sampling event. If 
the date of the scheduled sampling event is accelerated such that the TSAP cannot be completed and delivered at least 8 working days prior to the event, the TSAP shall be generated and transmitted as soon as possible after being notified of the sampling schedule change. If CPO does not provide the tank specific sampling information identified in Section 3.3 of this MOU within 9 working days, the TSAP cannot be issued at least 8 working days prior to the start of the sampling event. In this case, the TSAP will be issued within 1 day of receiving the sampling information from CPO. If any of the tank specific sampling information identified in Section 3.3 of this MOU must be revised by CPO, this information will be transmitted to TWRS Process Engineering within 1 day for immediate inclusion into a TSAP revision. The TSAP should then be revised within 1 day of receiving this information. In the event that the TSAP cannot be revised in this timeframe, sampling activities may proceed with concurrence of the changes and electronic mail direction from the TC. In this case, revision of the TSAP will be performed in parallel with the sampling activity.

The TSAP will include all applicable Data Quality Objectives (DQOs) which are approved and released when the TSAP is generated. If a DQO is issued or revised during generation of the TSAP or after the TSAP is issued, and these DQO additions or changes are sampling-related (as determined by the TC), these changes will be incorporated into the TSAP prior to initiation of sampling. If the DQO additions or changes are laboratory-related, the TC must evaluate whether there is sufficient time to incorporate the DQO additions or changes into the TSAP without delaying the start of the sampling and analysis event, or if the TSAP should be issued and subsequently revised. TWRS Process Engineering must determine that the continuation of the sampling and analysis event will not adversely affect the quality of the data produced. If the TC determines that the continuation of sampling and analysis will not adversely affect the data produced, CPO may initiate sampling and ship samples in accordance with the original TSAP, with electronic mail concurrence from the TC. As well, the 222-S Laboratory may work in accordance with the original TSAP until the TSAP revision is complete.

When changes to the TSAP are necessary, an Engineering Change Notice (ECN) shall be generated against the TSAP by TWRS Process Engineering in accordance with HNF-PRO-440, "Engineering Document Change Control Requirements" (PHMC 1997). The 222-S Laboratory Facility Planning/Production Manager and CPO managers will be on distribution for all TSAP ECNs.

In addition to transmitting the TSAP to the 222-S Laboratory, TWRS Process Engineering will also send a Request for Special Analysis (RSA) prior to sampling. The RSA is required by the 222-S Laboratory sample receiving procedure and communicates to the laboratory information regarding the known waste listings of the samples. 


\subsection{2-S Laboratory Performance Criteria}

The 222-S Laboratory will provide 20 analytical equivalency units (AEUs) of analytical workscope at $\$ 351,000$ per AEU during fiscal year 1999 , provided that an analytical budget of $\$ 7$ million is received from the Characterization Project. The estimates of cost, schedule, and laboratory capacity will be based upon the DQOs, Waste Information Requirements Document, the TSAPs, and the sampling schedule. TWRS Process Engineering will provide approved copies of these documents as applicable when requesting estimates.

The 222-S Laboratory is also responsible for reviewing and approving each TSAP prior to issuance. Unless special written, verbal, or electronic mail arrangements are made between the laboratory and TWRS Process Engineering (i.e., when a shorter turnaround time is required), the 222-S Laboratory should have 5 working days to review each TSAP and provide comments to TWRS Process Engineering.

\subsection{CPO Performance Criteria}

$\mathrm{CPO}$ is responsible for preparing the risers for sampling and issuing the work package prior to sampling. Riser preparations should be completed 10 working days prior to the sampling event for core samples, and two days prior to the sampling event for grab samples. Once this activity is completed, the riser numbers to be sampled and the work package number corresponding to the tank sampling event will be transmitted to TWRS Process Engineering within 1 working day for inclusion into the TSAP. Any changes with respect to the riser numbers to be sampled or the work package number to be used will be transmitted to TWRS Process Engineering within 1 working day for inclusion into a revision of the TSAP. No work may be initiated until the TC has concurred with the changes and has determined that these changes will not adversely affect the quality of the data produced.

$\mathrm{CPO}$ is also responsible for reviewing and approving each TSAP prior to issuance. Unless special written, verbal, or electronic mail arrangements are made between CPO and TWRS Process Engineering (i.e., when a shorter turnaround time is required), CPO should have 5 working days to review each TSAP and provide comments to TWRS Process Engineering.

In order to ensure that all appropriate blanks (lithium bromide and field) are obtained during a sampling event, CPO will place a procedural step in each work package instructing the CPO field crews to take these blanks. 
HNF-3578, REV. 0

\subsection{TWRS QA Performance Criteria}

TWRS QA is responsible for reviewing and approving each TSAP prior to issuance. Unless special written, verbal, or electronic mail arrangements are made between TWRS QA and TWRS Process Engineering (i.e., when a shorter turnaround time is required), TWRS QA should have 5 working days to review each TSAP and provide comments to TWRS Process Engineering. Review of the TSAP will be in accordance with the TSAP content requirements in Adams (1998). Only original TSAPs and quality-affecting revisions (such as DQO additions) require TWRS QA review and approval.

\subsection{2-S LABORATORY/CPO INTERFACE}

This section summarizes the expectations and performance measures pertaining to the activities performed by the 222-S Laboratory and CPO once a sampling event has been initiated.

\subsection{2-S Laboratory Performance Criteria}

In an effort to preclude generating a backlog of samples, the 222-S Laboratory commits to providing an average capability to extrude ten core segments per week. For processing purposes, a grab sampling event is counted as three core segments.

The 222-S Laboratory will distribute the Hot Cell daily report to both CPO and TWRS Process Engineering. This report will include at least 12 hour notification of when samples are to be extruded and when empty onsite transfer casks, PIGs, and doorstops are ready for pick-up by CPO. In general, PIGs are to be emptied and be ready for pick-up by CPO within 10 days of receipt at the 222-S Laboratory. However, the PIG turnaround time associated with high volume grab samples (one liter volume or greater) shall be negotiated on a case-by-case basis.

If problems are encountered (e.g., regarding chain-of-custody records or sample cask issues), the 222-S Laboratory will call CPO within 2 hours for assistance. For questions regarding vapor or grab samples, the point of contact is the Manager of CPO Field Sampling. The Manager of CPO Truck Sampling is the point of contact for questions regarding rotary and push mode core samples. This verbal notification must be followed within one hour by a confirmatory electronic mail message to the CPO point of contact. Additionally, the 222-S Laboratory Facility Planning/Production Manager will be notified of any problems in order to facilitate resolution with CPO.

To prevent laboratory extrusion delays, one Health Physics Technician has been designated to work in the Hot Cell area for fiscal year 1999. 
HNF-3578, REV. 0

\subsection{CPO Performance Criteria}

To assist the 222-S Laboratory in making the extrusion process more efficient, CPO will provide the hot cell crew with bails, locking pins, and other spare parts as needed throughout the year such that these items can be replaced without delaying Hot Cell activities.

When problems are encountered at the 222-S Laboratory and CPO is notified for assistance (see Section 4.1), CPO will correct any required paperwork or problem within 2 working days of notification, so as not to impact production in the hot cells facilities.

In addition to the actions above, CPO will assist the 222-S Laboratory in meeting the data package turnaround time stated in Section 6.2 of this MOU and in the Hanford Federal Facility Agreement and Consent Order (Ecology et al. 1989). Specifically, Ecology et al. (1989) requires that all single-shell tank data packages have a turnaround time of 216 days. This turnaround time begins with the date of the "individual sampling activities" (Ecology et al. 1989), which is interpreted as being the date when the last sample is obtained from the tank.

\subsection{TWRS PROCESS ENGINEERING/222-S LABORATORY INTERFACE}

This section summarizes the expectations and performance measures pertaining to the activities performed by TWRS Process Engineering and the 222-S Laboratory during sample analysis.

\subsection{TWRS Process Engineering Performance Criteria}

In order to provide real-time instructions on subsampling, the responsible TWRS Process Engineering TC will make every attempt to be present in the laboratory hot cell area during sample extrusions. If the responsible TC is not available, his/her backup TC or an alternate TC should be present. It is the responsibility of the TC to review the hot cell extrusion schedule provided at least 12 hours in advance of the extrusions and make initial contact with the extrusion chemist. However, any extrusion schedule changes must be communicated by the extrusion chemist to the TC or the secondary point of contact at 373-5554. If the TC is not available, the secondary point of contact will attempt to ensure that a TC is present to witness the extrusion(s). In the event of a schedule change, the extrusion group should wait 20 minutes after being notified that a TC is available before beginning extrusions to allow the TC to arrive at the laboratory.

Once the Tank Characterization Report is issued for a tank, any remaining samples in the 222-S Laboratory (i.e., in parent or archive jars) will be disposed of per 
HNF-3578, REV. 0

HNF-SD-WM-TRD-006, "Technical Basis for Disposition of Tank Waste Samples in Archive" (Adams et al. 1997).

\subsection{2-S Laboratory Performance Criteria}

In addition to the TC, the 222-S Laboratory project coordinator (PC) should be present during extrusions to assist with subsampling instruction. It is the PC's responsibility to ensure that the TSAP analytical requirements are entered into LABCORE and to interface with the TCs if issues arise with respect to the subsampling or analysis of tank samples. Analytical subsample aliquots (stored in T-handle carriers) and preparations may be discarded during the analysis process as required by the laboratory staff with concurrence by the PC.

\subsection{DATA REPORTING FUNCTIONS}

This section identifies the data reporting requirements pertaining to characterization sampling and analysis. The guidance provided in this MOU shall supersede all previously issued memoranda and documentation referring to data reporting formats.

\subsection{TWRS Process Engineering Performance Criteria}

In the event of a TSAP notification limit violation, the TC has the responsibility of issuing a letter, summarizing the results of the analysis which violated the limit and providing the statistical results of the 95 percent confidence interval on the mean calculations (Adams 1998). This letter must be issued within two working days of the TC receiving written (e.g., electronic mail) notification from the laboratory of the limit violation.

Once TWRS Process Engineering receives a Format IV data package (see Appendix A of this MOU) from the 222-S Laboratory, the responsible TC or TCR author (if different from the TC) will prepare the final draft TCR for review by the Department of Energy, Richland Field Office (DOE-RL). The TCR format will be in accordance with the approved, standard TCR template.

\subsection{2-S Laboratory Performance Criteria}

The 45 and 90 Day Safety Screening data reports are no longer necessary because of the implementation of the immediate notification system for TSAP limit violations; therefore, these reports will no longer be generated. Instead, the Format III reporting function will 
consist of a letter to be issued from the 222-S Laboratory to TWRS Process Engineering at such time that the safety screening analyses have been completed (see Appendix A). If any analytical result exceeds the safety screening notification limit criteria during the analysis process, the results will be reported to the TWRS Tank Farm Shift Operations Manager immediately by phone. This verbal notification must then be followed within one hour with a confirmatory electronic mail message to the Tank Farm Shift Operations Manager, the TWRS Process Engineering Data Assessment and Interpretation manager, and the responsible TC (see Appendix A of this MOU, Format I reporting).

In order to support the TCR effort, the 222-S Laboratory commits to making every effort to complete laboratory data reports according to the schedule specified in the individual TSAPs. It is recognized that programmatic priorities and project schedules may exceed the limited funding and available resources for short durations, requiring the delay of some work. When conflicts for resources arise, programmatic priorities will be determined by the Data Assessment and Interpretation Manager, and samples will be analyzed in accordance with that direction. The clock for these reports begins when the last sample or segment to be analyzed during that project is received at the laboratory loading dock. The Format IV data packages will be Supporting Documents which contain laboratory sample and QC results and data, chain-of-custody data, and a laboratory narrative (see Appendix A). Other data required to complete the DQO objectives (such as calculation of limits on a $95 \%$ confidence intervals on the mean) will not be part of these reports, but will instead be generated by TWRS Process Engineering at a later date. If errors are found in the data packages, corrections will be made via ECNs to the data packages and issued by the 222-S Laboratory within 5 working days of error notification. When a TSAP has additional analyses added by an ECN after the analytical turnaround time has begun, or a letter of instruction is issued instead of a TSAP for a nonroutine project, the turnaround time for the workscope will be negotiated between TWRS Process Engineering and the 222-S Laboratory on a case-by-case basis.

In addition to the data package turnaround times stated above, the Hanford Federal Facility Agreement and Consent Order (Ecology et al. 1989) requires that all single-shell tank data packages have a turnaround time of 216 days. This turnaround time, however, begins with the date of the "individual sampling activities" (Ecology et al. 1989), which is interpreted as being the date when the last sample is obtained from the tank.

\subsection{CPO Performance Criteria}

Once a sampling event has been completed, $\mathrm{CPO}$ is responsible for transmitting the results of the combustible gas meter or "sniff" data to TWRS Process Engineering. This data must be loaded into the Tank Waste Information Network System within 10 working days of the date that the last sample was removed from the tank. 
HNF-3578, REV. 0

\subsection{REFERENCES}

Adams, M.R., 1998, Tank Waste Remediation System Process Engineering Instruction Manual, HNF-SD-WM-PROC-021, Rev. 1E, Lockheed Martin Hanford Corporation, Richland, Washington.

Adams, M.R., et al., 1997, Technical Basis for Disposition of Tank Waste Samples in Archive, HNF-SD-WM-TRD-006, Rev. 0, Lockheed Martin Hanford Corporation, Richland, Washington.

Board, D.C., 1998, Tank Waste Remediation System, Characterization Project, Quality Policies, WHC-SD-WM-QAPP-025, Rev. 4, Lockheed Martin Hanford Corporation, Richland, Washington.

DOE, 1997, Hanford Analytical Services Quality Assurance Requirements Document, DOE/RL-96-68, Rev. 1, U.S. Department of Energy, Richland Operations Office, Richland, Washington.

Ecology, EPA, and DOE, 1989, Hanford Federal Facilities Agreement and Consent Order, 2 vols, Washington State Department of Ecology, U.S. Environmental Protection Agency, U.S. Department of Energy, Olympia, Washington.

Markel, L.P., 1998, 222-S Laboratory Quality Assurance Plan, WHC-SD-CP-QAPP-016, Rev. 3A, Rust Federal Services of Hanford, Inc., Richland, Washington.

PHMC, 1997, "Engineering Document Change Control Requirements", HNF-PRO-440, Rev. 1, Lockheed Martin Hanford Contract, Richland, Washington. 
HNF-3578, REV. 0

APPENDIX A

\section{LABORATORY DATA REPORTING}

FORMAT REQUIREMENTS 
HNF-3578, REV. 0

\section{LABORATORY DATA REPORTING FORMAT REQUIREMENTS}

\section{A1.0 INTRODUCTION}

The results of the analyses required in the Tank Sampling and Analysis Plan (TSAP) for condensed phase waste (i.e., non-vapor) shall be documented using the following reporting formats. Reporting format requirements for vapor sampling and analysis events may be found in (Douglas et al. 1996). Each sampling and analysis event could include data reported using several of these formats. The specific reporting format categories shall be identified in each TSAP or other work-authorizing document. The lowest category of data reporting that meets the program element's requirements shall be specified. All data reports must be:

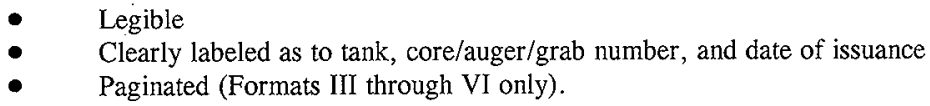

\section{A2.0 FORMAT I REPORTING - IMMEDIATE NOTIFICATION}

If the program or sampling activity requires immediate notification of a result that exceeds an established safety or operational threshold limit, the laboratory shall call the appropriate tank farm operations shift manager immediately upon the first review of the laboratory data by the responsible scientist. This verbal notification must be followed by electronic notification to the tank farm operations shift manager, the Tank Waste Remediation System (TWRS) Process Engineering Data Assessment and Interpretation manager, and the tank coordinator responsible for the tank.

This type of reporting does not require any supporting raw data, quality control (QC) information, or documentation of analytical procedure numbers used, and does not have any formal validation requirements. The contacts for reporting where notification limits (as identified in the TSAP or other work-authorizing document) are exceeded are as follows:Double Shell Tank operation shift manager at 373-2689 for samples from double shell waste tanks, and Single Shell Tank operation shift manager at 373-3475 for samples from single shell waste tanks. The TSAP shall clearly identify the action limits for each parameter and any other follow up activities (e.g., secondary analyses) that may be required. This documentation may also identify personnel to be notified in addition to those given above. 
HNF-3578, REV. 0

\section{A3.0 FORMAT II REPORTING - PROCESS CONTROL}

If the data from a program are needed as soon as possible to control a process or operation, it may be reported using a Laboratory Information Management Systems report, by electronic mail, or as a letter report as specified in the TSAP or other work-authorizing document. This type of report may also be used to support development activities or projects. This report does not require that supporting raw data, $\mathrm{QC}$ results, or associated analytical procedure numbers be included. Results require review and approval by the cognizant scientist or manager of the laboratory operation. The data do not require third party validation.

\section{A4.0 FORMAT III REPORTING - SAFETY SCREENING}

Analyses that were identified in the safety screening data quality objectives (DQO) effort and measured to support the safety screening activities must be completed within 45 days of receiving the last sample from the sampling event at the laboratory sample receiving/loading dock. If no safety screening criteria were exceeded, the laboratory shall electronically notify the Tank Coordinator (TC), which shall be followed with a letter confirming work completion.

If any analysis results exceeded the safety screening criteria, a letter identifying the results that exceeded the criteria will be issued. At such time, secondary analyses commensurate with the governing TSAP will be performed. These secondary analyses must be completed within 90 days of receipt of the last sample at the laboratory loading dock. When the secondary analyses are complete, the laboratory shall issue a letter to the TC confirming work completion. If any secondary analysis notification limits were exceeded, the results that exceeded the limits shall be identified.

\section{A5.0 FORMAT IV REPORTING - WASTE MANAGEMENT DATA PACKAGE}

This category of reporting is aimed at projects where the data are not intended to support regulatory compliance (see Section A6.0 of this MOU) at the present time, but may need to be used later for regulatory purposes. The objective of the data package is to collect the information from the characterization of the samples that is needed to verify or reproduce the reported results at a later date. This type of report may also be desirable for data that is expected to receive extensive review from organizations outside of TWRS. Because the regulatory or end use of the data may not be defined at the time of analysis, no third party validation of the data is required. Therefore, this report resembles a regulatory data package without third-party validation. The data package should be prepared by tank and include the data for all core, grab, or auger samples, including composites, segments, subsegments, 


\section{HNF-3578, REV. 0}

drainable liquids, and associated blanks taken and analyzed from the tank during a single sampling activity. The recommended reporting format and the raw data that shall be included for each sampling activity and analysis are summarized below. This data package shall be issued as a document approved for public release through the document control system. The raw data shall be accessible to the program until the respective waste tank is closed or the waste is treated and in accordance with the laboratory's Records Inventory and Disposition Schedule.

The data package should be organized into two major parts: (1) a summary report section; and (2) a raw data compilation. Both data package sections will be organized according to the type of analyses or activity where the data were generated. The summary report section should be comprised of two subsections: (1) a narrative describing the methods used and any unusual sample or QC results from each analysis or activity; and (2) summary tables of the sample and QC results. Each raw data activity should be organized by analysis type and batch or by the time period when the activity occurred. For most analytical measurements, the batch arrangement should require the least duplication.

\section{A5.1 Summary Report Section}

\section{A5.1.1 Narrative}

Introduction. The report should contain a summary that either clearly states that no criteria were exceeded or identifies those parameters that exceeded the established criteria. The summary shall identify (1) the tank; (2) core, auger, or grab sample(s); (3) segment or samples and subsegments or subsamples included in the report; and (4) the TSAP or other work-authorizing documentation used as the basis for the analyses.

Description of the Samples. Briefly describe the sample's physical characteristics (color, homogeneity, texture). Identify any unusual properties of the sample and any problems associated with subsampling or preparation. For core samples, the mass of recovered drainable liquid and the mass of recovered solids should be provided.

Discussion of Analytical Results. The following items should be discussed in this section:

Description of the analytical methods used (e.g., cyanide quantitation by titration or spectrophotometry) and any changes to the TSAP-referenced procedure that may have been necessary to analyze the samples. The procedure number and revision will also be referenced in this section. 
HNF-3578, REV. 0

Brief description of digestion/dissolution, preparation/separation, or extraction and analytical methods used.

Identification of any sample QC or method problems (i.e., precision, accuracy, sensitivity) encountered during the analysis that may impact the results and their use for making safety, operational, or other decisions.

Discussion of any observations that impact the overall quality of the analytical results (i.e., sample integrity).

Describe any activities (reruns, replicate analyses, procedure modifications) that may have been used to verify the data.

Description of any assumptions, corrections applied to the data, use of the method of standard additions, or calculations that may be important to interpretation of the data.

Identification of any samples not analyzed or analyses required by the respective TSAP or other work-authorizing document that were not performed, and on what sample each missing analysis was to be run.

References. Any references (e.g., the TSAP, LOI, or extrusion logbook used in the hot cells) should be listed in this section.

\section{A5.1.2 Data Summary}

The data summaries have many common areas for each type of analysis. These summaries may be presented in different formats depending on the type of analysis and the customer's need. The QC results, which should be reported are those needed to evaluate the sample, results (duplicates, spikes, control standards, and preparation blanks). The following information is considered important to the data summaries for most chemical and radiochemical measurements:

- $\quad$ Sample identification, including the laboratory sample number, sample location (segment/core number, auger or grab sample number), and sample type (composite, subsegment, drainable liquid, field blank, preparation)

Laboratory control standard, including percent recovery 
HNF-3578, REV. 0

- Preparation blanks, including identity and concentration of each constituent identified

- $\quad$ Sample and duplicate results, as well as results from replicate analyses

- $\quad$ Results of spikes and tracers, including amount spiked, percent recovery, and relative percent difference (RPD) for each duplicate sample in the analytical batch

Surrogate analysis (GC/MS, GC, and HPLC analyses) including amount of spike and percent recovery for each surrogate

Internal standard results

Detection limits

Counting errors

\section{A5.2 Raw Data Section}

The raw data from each characterization activity or each type of measurement will vary depending on the activity (hot cell, sample receipt) or the analytical instrumentation. The raw data will be used to confirm that the results of the sample and QC analyses were performed and calculated properly and that the analytical system was in control while the data was being generated.

At a minimum, the raw data associated with the results discussed in Section A5.1 are to be included in this section. The record copy of the remaining supporting data for the Format IV data package is retained by the laboratory, although it may not be included in the data package at the discretion of the laboratory. Supporting data includes, but is not limited to, the following information:

\footnotetext{
- $\quad$ Results of standard additions

- $\quad$ Results of serial dilutions

- $\quad$ All raw data necessary to check calculation of analyte concentration (e.g., calibration data)
} 
HNF-3578, REV. 0

Mass spectrum including spectra of standards (one for each report for each compound detected) and spectra of analytes detected

Calculation sheets for sample and QC sample measurement that document the amount of sample/spike/standard used in the measurement and the instrument data output (if manual). These work sheets shall identify the instrument or analytical system used and any special operating parameters.

\section{A5.3 Recommended Data Package Structure}

The preferred organization of the data will depend on the data user. Some users may want to see all the analyte data on a single sample (organized by sample), whereas another data user may want to see a single analyte (organized by analyte) for all the samples taken in the sampling activity. The following outline is recommended for the structure of the data package. If the TSAP does not specify an alternative format, this outline should be used as the default data package format.

I. Table of contents

- List of tables

- List of sample analysis worklists

II. Narrative

- Reference to work directives

- Tank and sample identification

- Sample description

- Subsample identification

- Analytical procedures used for each analysis

- Range or average results per analysis, including any results which exceed the QC specifications or TSAP notification limits

III. Sample breakdown figures or other attachments that are identified in the TSAP

IV. Data Summary Tables

V. Sample Photographs

VI. Chain-of-Custody Forms

VII. Raw Data sorted by analysis, including extrusion and sample preparation worklists 
HNF-3578, REV. 0

\section{A6.0 FORMAT V REPORTING - RESOURCE CONSERVATION AND RECOVERY ACT (RCRA) DATA PACKAGE}

This data package is intended to support projects and sampling activities where the data is used to meet regulatory compliance areas and could be subject to litigation. The data package has many of the same requirements for data summaries and narratives as Format IV packages, but also requires that the data be validatable by third-party validation and standalone using validation procedures established for the waste characterization project. This report includes (1) a data summary of the results for sample and QC measurements; and (2) a narrative similar to that described for the Format IV report. All raw data associated with the analysis project shall be included in the Format $\mathrm{V}$ report. The recommended reporting format is similar to the Format IV report described above. This data package shall be issued as a document approved for public release through the document control system.

In addition to the requirements of the Format IV data package, the Format V data package shall include the following information:

Laboratory control standard concentrations and all raw data (including
logbook pages) needed to check the calculation of the percent recovery
All raw data needed to check the calculation of the reported blanks
All raw data needed to check the RPDs and percent recoveries reported
ICP-OES and ICP-MS sensitivity factors and linear ranges (when
applicable)
Metal interference check-sample results
Initial and continuous calibration raw data
Instrument tuning data and instrument run logs
- $\quad$ Column performance check with the standard, including the chromatogram
Chromatograms (for organic analyses)
- $\quad$ Sample identification
- $\quad$ Method identification


HNF-3578, REV. 0

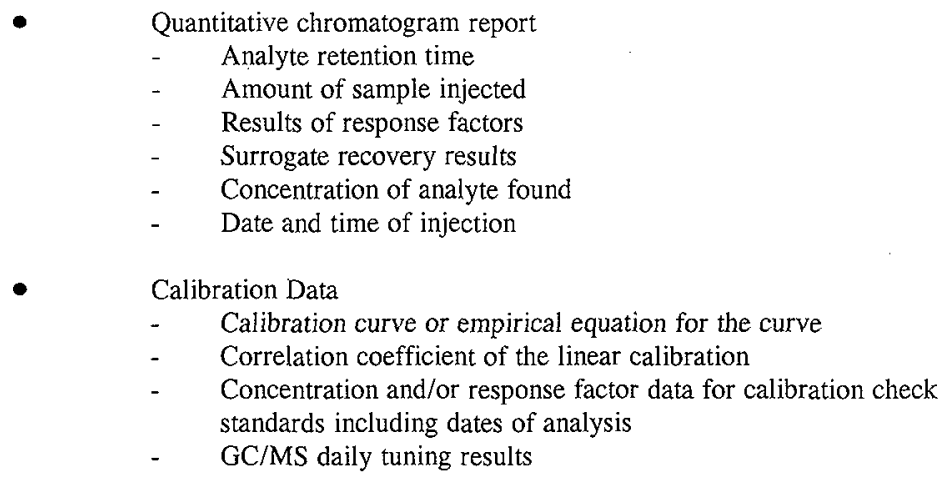

\section{A7.0 FORMAT VI REPORTING - SPECIAL DATA REPORTS}

Data reporting requirements that do not fall into the above categories or which take exception to some of the requirements in the above categories may be implemented by incorporating a modified format of reporting into the TSAP or other work-authorizing document.

\section{A8.0 REFERENCES}

Douglas, J.G., M. Stauffer, R.D. Mahon, and T.C. Trible, Required Elements and Format for Tank Vapor Sample and Analysis Data Packages, WHC-SD-WM-RPT-280, Rev. 0, SGN Eurisys Services Corporation, Richland, Washington. 


\section{DISTRIBUTION SHEET}

\begin{tabular}{|c|c|c|c|c|c|}
\hline \multirow{2}{*}{$\begin{array}{l}\text { To } \\
\text { Distribution }\end{array}$} & \multirow{2}{*}{\multicolumn{3}{|c|}{$\begin{array}{l}\text { From } \\
\text { Technical Basis and Planning }\end{array}$}} & \multicolumn{2}{|l|}{ Page 1 of 2} \\
\hline & & & & \multicolumn{2}{|c|}{ Date $\quad 11 / 09 / 98$} \\
\hline \multirow{2}{*}{\multicolumn{4}{|c|}{$\begin{array}{l}\text { Project Title/Work Order } \\
\text { HNF-3578, Rev. 0, "Fiscal Year } 1999 \text { Memorandum of Understanding } \\
\text { for the TWRS Characterization Project" }\end{array}$}} & \multicolumn{2}{|c|}{ EDT No. EDT-622492 } \\
\hline & & & & \multicolumn{2}{|l|}{ ECN No. N/A } \\
\hline Name & MSIN & $\begin{array}{l}\text { Text } \\
\text { With } \\
\text { Al1 } \\
\text { Attach. }\end{array}$ & Text On1y & $\begin{array}{l}\text { Attach.' } \\
\text { Appendix } \\
\text { Only }\end{array}$ & $\begin{array}{c}\text { EDT/ECN } \\
\text { Only }\end{array}$ \\
\hline
\end{tabular}

$\underline{U}$ S. Department of Energy -

Richland Field office

C. A. Babe ?

J. F. Thompson

DOE/RL Reading Room

$\begin{array}{ll}\text { S7-54 } & X \\ 57-54 & X \\ H 2-53 & X\end{array}$

Eluor Daniel Hanford, Inc.

D. J. Washenfelder

$57-40 \quad X$

Lockheed Martin Hanford Corp.

M. R. Adams

R. P. Anantatmula

D. L. Banning

D. C. Board

J. M. Conner

S. D. Estey

J. G. Field

K. D. Fowler

K. M. HaIl

T. A. $\mathrm{Hu}$

J. W. Hunt

J. Jo

J. A. Johnston

W. J. Kennedy

J. G. Kristofzski

J. S. Lee

J. G. Lewis

D. J. McCain

S. G. McKinney

D. M. Nguyen

M. A. Payne

R. S. Popielarczyk

J. H. Rasmussen

L. M. Sasaki

R. D. Schreiber

B. C. Simpson

J. S. Sparks

G. A. Stanton

L. A. Stauffer

A. M. Templeton

R. R. Thompson

R2-12

R1-30

$\mathrm{R} 2-12$

S7-07

R2-12

R2-11

R2-12

R2-11

R2-12

R2-12

R2-12

R2-12

R2-12

S7-03

S7-01

S7-03

S7-01

R2-12

R2-12

R2-12

R2-58

R2-58

R2-12

R2-12

R2-12

R2-12

57-07

S7-01

R2-11

R2-12

R2-12

T.C.S.R.C.

R1-10

$x$
$x$
$x$

$x$

$x$
$x$
$x$
$x$
$x$
$x$
$x$
$x$
$x$
$x$
$x$
$x$
$x$
$x$
$x$
$x$
$x$
$x$
$x$
$x$
$x$
$x$
$x$
$x$
$x$
$x$
$x$
$x$
$x$
$x$
$x$
$x$
$x$
$x$ 


\section{DISTRIBUTION SHEET}

\begin{tabular}{|c|c|c|c|c|c|}
\hline \multirow{2}{*}{$\begin{array}{l}\text { To } \\
\quad \text { Distribution }\end{array}$} & \multirow{2}{*}{\multicolumn{3}{|c|}{$\begin{array}{l}\text { From } \\
\text { Technical Basis and PTanning }\end{array}$}} & \multicolumn{2}{|l|}{ Page 2 of 2} \\
\hline & & & & \multicolumn{2}{|c|}{ Date $\quad 11 / 09 / 98$} \\
\hline \multicolumn{4}{|l|}{ Project Title/Work Order } & \multicolumn{2}{|c|}{ EDT No. $\quad$ EDT-622492 } \\
\hline \multicolumn{4}{|c|}{$\begin{array}{l}\text { HNF-3578, Rev. 0, "Fiscal Year } 1999 \text { Memorandum of Understanding } \\
\text { for the TWRS Characterization Project" }\end{array}$} & \multicolumn{2}{|c|}{ ECN No. N/A } \\
\hline Name & MSIN & $\begin{array}{c}\text { Text } \\
\text { With } \\
\text { A11 } \\
\text { Attach. }\end{array}$ & Text only & $\begin{array}{l}\text { Attach.\%. } \\
\text { Appendix } \\
\text { Onty }\end{array}$ & $\begin{array}{l}\text { EDT/ECN } \\
\text { Only }\end{array}$ \\
\hline $\begin{array}{l}\text { Lockheed Martin Services, Inc. } \\
\text { Central Files }\end{array}$ & $\mathrm{Bl}-07$ & $x$ & & & \\
\hline $\begin{array}{l}\text { Los Alamos Techical Associates } \\
\text { R. W. Lambie }\end{array}$ & $57-04$ & $x$ & & & \\
\hline $\begin{array}{l}\text { Waste Management Services of } H \\
\text { R. A. Esch } \\
\text { R. K. Fuller } \\
\text { D. B. Hardy } \\
\text { C. M. Seide } \\
\text { F. H. Steen }\end{array}$ & $\begin{array}{r}\text { Inc. } \\
\text { T6-12 } \\
\text { T6-12 } \\
\text { T6-12 } \\
\text { S3-30 } \\
\text { T6-12 }\end{array}$ & $\begin{array}{l}x \\
x \\
x \\
x \\
x\end{array}$ & & & \\
\hline
\end{tabular}

